\title{
Socio-political issues of Fata, a historical
}

\section{And contemporary perspective}

\author{
Abid Latif \\ M. Phil Scholar \\ Department of Political Science \\ The Islamia University of Bahawalpur \\ Prof. Dr. Razia Musarrat (Corresponding author) \\ Chairperson, Department of Political Science \\ The Islamia University of Bahawalpur \\ Email: drrazia_mussarat@yahoo.com
}

Received:October 07, 2012 Accepted:November 25, 2012 DOI:10.5296/jpag.v2i4.3208

\begin{abstract}
Tribal areas of Pakistan have become the hotbed of ensuing insurgency against the state and the breading ground of terrorism. The fault lines of this simmering crisis is the Geography, the Tribal Genealogical lineage, the porous Durand line, the FCR, the Tribal Genealogical lineage, the porous Durand line, the FCR, Pashtunwali and the gestation of the New Great Game in the neighborhood. All the four Drivers of conflict resolutions, the Pashtunwali, the Political Agent, the Jirga and the Malik are fast becoming redundant and meaningless in the context of Taliban Phenomena. Taliban have emerged as a network with a clear ability to penetrate all the layers of Social strata, feeding upon the backwardness and primitiveness of the area in the fields of social and political sectors. This paper identifies the major chasm of tribal society and the effect there in FATA has become a breading ground of extremism with all the ingredients available.At the proximity of physical and ideological convenience. Corrective measures in socio-political and economic plan are if delayed further, will result into uncontrolled chaos and instability with far reaching effects. . In this research paper an endeavors is made to highlight all such fault lines and grey areas with special emphasis on Waziristan agency, which is known as the breeding grounds of this menace.
\end{abstract}

Keywords: Tribal area, terrorism, instability, Pashtunwali, Jirga, War of perceptions, Waziristan Anchorage 


\section{Macrothink}

\section{Introduction}

FATA is a place with its own pronounced peculiarities. Constitutionally it is not equal amongst the equals. The code of conduct or the law of area is cultural in the form of Pakhtunwali, which is enforced through different types of Jirgas.

Government of Pakistan controls this area through FCR, the draconian law with many pitfalls. Taliban exploit the cultural dogmas of Pashtun society and the fault lines created by the misinterpretation of Pakhtunwali

\subsection{Tribes}

The Tribal area of Pakistan can be divided into three categories, Federally Administrated Tribal Areas (FATA), provincially administrated Tribal areas (PATA) of Khyber Puktun Khawa and the provincially administrated tribal areas of (PATA) of Baluchistan.

Among Pashtuns the distinction prevails amongst the people living in mountains and in plains (Caroe, 1965, p.25). The number of tribes in genealogical order is in hundreds but the main tribes of FATA are:-

\section{Genealogical Delineation of Main Tribes}

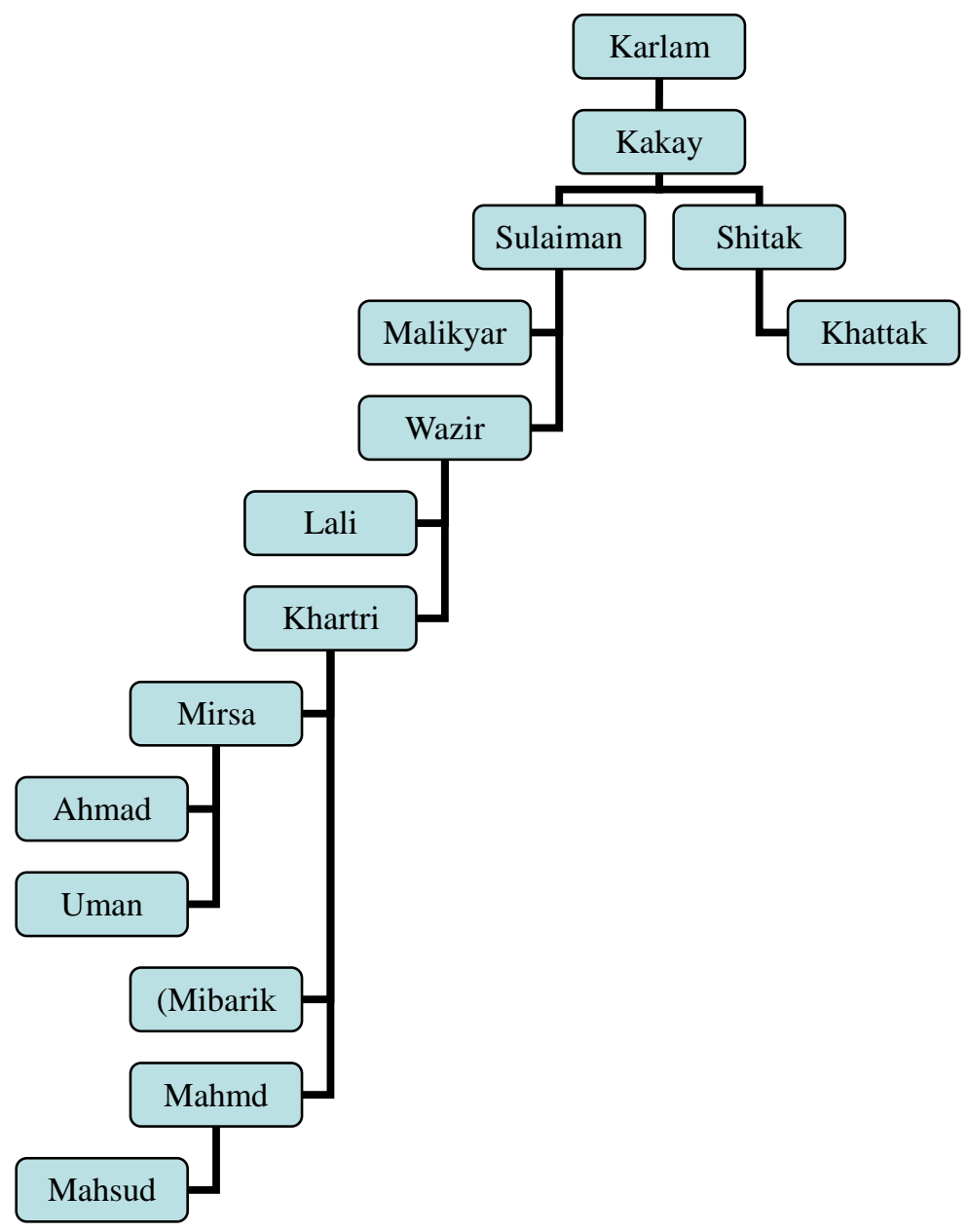




\section{Peculiarities of FATA}

FATA is administratively divided into seven political agencies, Khyber, Bajaur, North Waziristan, Mohmand, Orakzai, South Waziristan and Khurram. It also comprises of six frontier regions these are FR tank, FR Peshawar, FR Bannu, FR Kohat, FR D.I Khan and FR Lakki Marwat.

FATA has a special status. During the time of independence, Quaid-e-Azam assured the tribal jirga that the Tribal area will enjoy the same status as that of before partition (Caroe, 1965, p.435). Presently this area has few peculiarities which are important to highlight before indulging into further discussion:-
a. Constitution of Pakistan designates it as special area.
b. Indirect administration through Maliks is enforced in FATA with the principle of collective responsibility.
c. Pakistani courts have no jurisdiction in FATA area.
d. Pakhtunwali is the law of the tribes based on tribal custom.
e. FCR is the legal instrument for political agent to govern.
f. Tribes identify them selves in tribes first rather than part of a territory.
g. Political party act is not enforced in tribal area, however right of Adult franchise is lately granted.
h. Lack of urban Amenities.
i. Tribesman pays no taxes.
j. Disputes are settled through Jirga.
k. Tribal area is in asymmetrical relation with the rest of the country due to lack of advancement and necessary moderinizaiton (Khan,2008, pp.16-19).

These peculiarities are actually the crucible where all the under currents of present day situation merges. These are the same off handed issues which Taliban exploit to their advantage.

\subsection{Constitutional Status of FATA}

As per the tacit understanding with Quaid-e-Azam the status of tribal areas were kept unchanged in the constitution of 1956 (Constitution of Pakistan, 1956, p42) ${ }^{1}$. In Article 1 of the 1973 constitution of Pakistan, FATA is included as one of the territories of Pakistan; Article 246 stipulates same 13 Agencies and frontier regions that comprise the FATA.

Same way again in the constitution of 1973 under article 247, central and provincial laws were barred to be applied to the tribal areas due to the peculiarity of its dynamics 


\section{Macrothink}

(Constitution of Pakistan, 1973, p.97). The constitution in article 246 excluded the tribal area from the domain of fundamental human rights. Articles 25 to 28 also exclude the area from the protection of law granted to every citizen. Under article 247 President was Chief Executive of the tribal areas along a different administrative system.

Recently using the powers inferred by article 51(6) of the constitution, president of Pakistan extended the electoral system based on adult franchise to tribal area.

The constitution of Pakistan is not evenly applied to the FATA. Giving right of adult franchise to people without introducing the political parties had created a chasm which Taliban exploited. This act has mitigated the influence of Malik as now, the youth has got the right to vote without any political training etc. More over the Carte blanche given to president on one hand and the sans presence of judicial blanket on the other has again vacated the political space for Taliban. Traditionally this was to be filled by malik, but due to killing of our 200 Maliks the institution has gone so weak that it is now enable to recuperate.

\subsection{Pakhtunwali - The Tribal Magna Carta}

Pakhtunwali can be termed as the unwritten constitution of the tribal people. They are proud to be part of Pakhtunwali system. Although few people misuse this for financial gains during diputes (Nawaz, 2009, p.25). It actually manages the complete aspect of tribal life. It is based on different dogmas and principles; each principle is an independent unwritten law. The Pakhtunwali revolves around the constitution of Hujra and Jirga. Jirga being the vehicle of this tradition is the lynch pin of the complete system. There are numerous dogmas of Pakhtunwali, only relevant will be covered in this study, however it is important to first highlight the institution of Jirga.

\section{Dispute Resolution Preferences}

Jirga is defined as an assembly of elders, it is the forum for a conflict resolution. In tribal areas now five type of Mechanism are available to the people:-
a. Jirga
b. Local Leaders.
c. Court
d. Mullah
e. Taliban

\section{How Jirga Work}

Whatever means are applied, Jirga is the most popular. It is of three types, the FCR Jirga, which is sponsored by government also known as Sarkari Jirga, Olasi Jirga (people), and the Loya (Grand Jirga).

Jirga process usually covers the following stages:-

a. Complaint is initiated and jirga is called. Elders can also take suo-motto 
notice.

b. Members of jirga appointed.

c. Announcing a Teega (ceasefire) in case of hostilities.

d. Framing of charges.

e. Taking a Waak (accreditation) from the side.

f. Preliminary inquiry

g. Initiation of argument

h. Visit of sites etc if required.

i. Conclusion and finding.

j. Announcement of decision

k. Right to appeal

1. Execution (Khan, 2008, p.104)

\section{Dogmas of Pakhtunwali:-}

It seems to be a very effective means to deliver justice. Taliban being part of the same culture and well conversant with Pakhtunwali, use the same to their benefit. The clauses, dogmas and principles of the tribal Magna Carta which are being misused needs elaboration to reach a synthesizing conclusion and a way forward. The percepts are:-

\section{a. Melmaste:}

It means the display, practice and accentuation of extreme hospitality. Every house has a hujra so that this vitual is diligently performed. Taliban and Al-Qaida fairly use this dogma while criss crossing the tribal areas (Shinwari, 2010, p.53)

\section{b. Nanawatay:}

It means asking for the mercy and forgiveness against any misdemeanor or crime. The wrong doer compensates the aggrieved party. The cattle, property and sometime Zanana (women) are taken in compensation.

\section{c. Badraga:}

Badraga means safe passage or demanding the safety of passage in lieu of a favor or money. In tribal culture if during Badraga harm occurs to someone than the complete tribe will take the revenge for that. The criminals from settled areas of Pakistan and even the terrorists once out of favor use badraga to cross territories (Khan,2008,p.109).

\section{d. Badal:}

Revenge is the corner stone of tranquility and maintenance of peace in tribal areas. It is a justice based on tit for tat principles. Whenever a drone attack takes place and collateral 


\section{I Macrothink}

Journal of Public Administration and Governance

ISSN 2161-7104

2012, Vol. 2, No. 4

damage is done, the obscurantist of the area encourage the aggrieved party to invoke badal by joining their ranks.

\section{e. Baramtha:}

Kidnapping a person who has defaulted financially. This dogma is misused with the pretext to acquire monetary resources by Taliban.

\section{f. Ghariat:}

It is the Namoos and the display of courage for the prestige of family and tribe.

\section{g. Swara:}

Is the custom of giving the hand of the daughter or sister of the killer in marriage to the son or brother of the aggrieved party.

\section{h. Panah:}

It is protection or provision of safe house once a offender enters the hujra and asks for protection. Mullah Omer repeatedly quoted to his companions that how can he hand over Osama Bin Ladin to the infidels (Kuehn,2012, pp.77-82).

These few pashtu clichés or the dogmas of Pakhtunwali are not invoked by Taliban through Jirgas, rather they exploit the spirit of those principles, as these are imbibed into the heart of every tribal person.

\section{Administrative Structure of FATA}

As described by the constitution of Pakistan, FATA is administrated through special injunctions. The Federal government retained the control of FATA with itself because of few cardinal issues. Mainly there are three reasons. The Durand line is the Achilles heel of this region. Already the issue of Pashtunistan has mired the relations of both Afghanistan and Pakistan (Caroe,1965,p.38). Federal government was desirous to be in direct control of Durand line issue therefore it kept FATA under its own auspices.

Unfortunately tribal areas are the poorest and most backward region in Pakistan. Initially the consideration right after partition was to infuse development project on a gigantic scale, which was only possible through federal control.

All along, there was no change in the system of governance and till to date the government of Pakistan deal with Maliks through the good offices of PA. The direct control by the people of Tribal area has not yet established.

\section{Administrative Hierarchy of Tribal Area}

Pakistan is a parliamentary democracy. Unfortunately the biggest function of any democracy is to assimilate all the regions of a particular country through political process into a homogeneous entity. Prime Minister has the executive power to rule the country. In case of FATA the president enjoys the same power. Paradoxically on behalf of president, governor rules the area. The Jurisdiction of Pakistani court and the application of Basic rights is 
already a soar issue due to which the area is left at the mercy of either the traditional elders or the obscurantist who fill the political vacuum.

\section{Administrative Anchorage- Political Agent}

The political agent is the administrative patriarch of the Agency. All the seven agencies have their own PAs, he runs the administration by the assistance of assistant political agent, two / three Tehsildar and four/five Naïb Tehsildars. Political tehsildar is the coordinating officer of the agency headquarters. For the law and order the political administration has a force of khassadars and militia. The PA is directly under the governor.

The duties of political agent varies, the foremost is the maintenance of peace through a system of controlling roads. He is responsible for the maintenance of law and order, he is also the collector of revenue in the area, implements development plan and is the chief judicial officer of the agency under FCR. He issues different permit to support the local economy of his agency. He has some secrets funds and allowances to doll out for political reasons (Nuri, 2005, p.37).

The peace in the area is directly proportional to the administrative acumen of the political agent. Upheaval in the atmosphere of general peace is an indicator that people are not happy with their political agent. For the last sixty five years no change has been made to make this system more transparent in nature.

\section{Frontier Crimes Regulation- Legal Tinder Box.}

The Tribals do not equate the people of mountains with the people of plains. Britishers lavishly applied this principle by formulating laws for the Pashtuns of plains and leaving the tribal of mountain embedded in tribalism.

For the convergence of military dominance like a socio-cultural legitimacy, probably frontier crimes regulations were introduced.

The present day FCR was introduced in 1872 as the Punjab frontier crimes regulations, revised in 1887 and was promulgated with amendments in the new Province of NWFP in 1901 as FCR. The Britishers came with a load full of Anglo Saxon laws which they introduced in the subcontinent. But for tribal people they introduced the FCR, as per the Caroe the regulation was a farce as it neither satisfied law nor custom.

The Tribal custom requires that aggrieved be compensated rather than focusing on the punishment of aggressor. The FCR does the exact opposite in which the aggressor is punished while the aggrieved is hardly compensated.

There is also a misnomer that only FCR is applicable to FATA, the Pakistan Penal Code, the criminal procedure, Evidence act and Hudood Ordinance etc are very much enacted for FATA; the problem is the non availability of available enforcement mechanism (Ghani, 2011,p.8).

\section{Durand Line - The Achilles Heel}

Pakistan and Afghanistan are neighbors with historical rifts due to the historic divide over the 
Pushtun. The Pashtunistan issue is the bone of contention which is it self based on the viability and legality of Durand Line. This line divide the Pashtun tribes on either side and as the tribal align himself with tribes rather than territory, therefore they literary do not recognize it to be a hurdle in their movement to and fro.

It is 2450 kilometer long, named after Sir Mortimer Durand in 1893, who demarcated it. $\mathrm{N}$

\section{Durand Line International Frontier between Pakistan and Afghanistan}

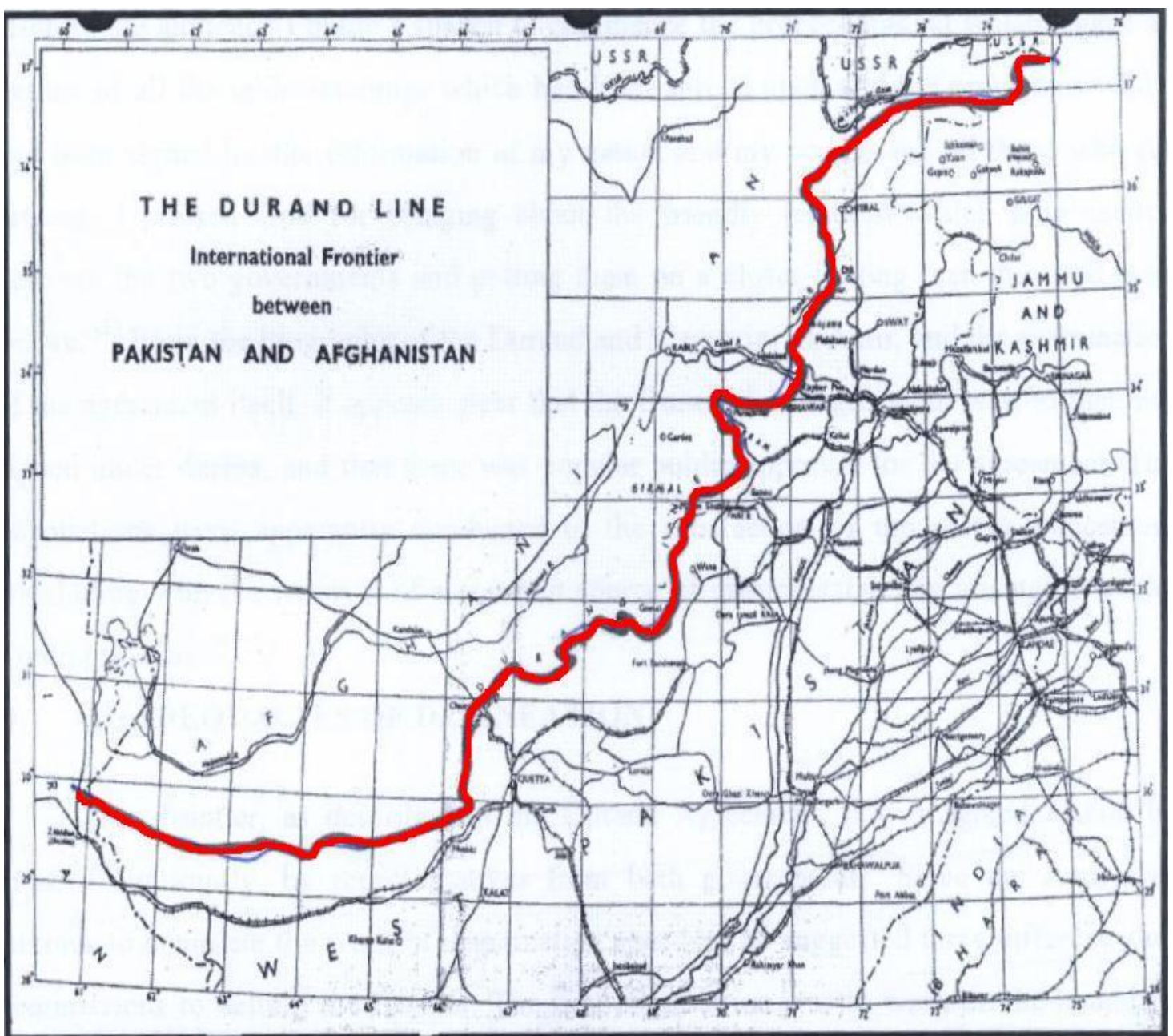

Source: Tariq Mahmood, Durand Line, South Asia new trouble spot, A thesis submitted to Naval postgraduate college, Washington, 2005 , p.19

Afghanistan. The Frontier as described by the agreement was to be demarcated in four stages, one near the Khyber Pass, second on Kurram Valey and south of it, thirdly at Baluchistan and fourth from Mohmand till Waziristan, the last stage could not took place due to armed resistance to boundary commission in Waziristan. Tribal resisted the demarcation and took Durand Line as an insult to their nomadic life style along the frontier.

After 1947 the dispute emerged when Afghanistan took the stance that Durand Line agreement was signed under duress and that too with British Empire, Pakistan is not the 
signatory so the line is disputed. In 1950 secretary of state of common wealth Mr. Nuel Baker said "his majesty's government in the United Kingdom has seen with regret the disagreements between the governments of Pakistan and Afghanistan about the States of the territories on the North West Frontier.

It is his Majesty's government view that Pakistan is in international law the inheritor of the rights and duties of the old government of India and of his Majesty's Government in the United Kingdom in these territories and that the Durand line is the international Frontier"'( Noor-Ul-Haq,2012, p.12). Afghan also thinks that Durand line agreement has a life of hundred years therefore the agreement has lapsed in 1993, therefore the areas till Indus be returned to Afghanistan.

The Durand Line is a permeable membrane, flow or the fluidity can not be checked, till the Socio-economic conditions of these dwelling on both sides are changed. Same tribes and people on both sides leave the international border as cartographic entity on map, a free to all country express way on the ground.

\section{Jihadi Foot Print in Tribal Area}

Pakistan is presently facing the threat of terrorism in multi dimensional way. The manifestation of this is basically in four facets:-

Firstly the Afghan Taliban who are fighting the allied forces but have an ultimate agenda of trans-frontier maneuvers, secondly the threat of Pakistan Taliban who are engaged in an open insurgency against the state in FATA area. Thirdly is the threat of plethora of Tribal militia and extremist networks active in the FATA area.

Fourth is the threat of sectarian groups who are active in the complete length and breadth of the country but use FATA as a refugee whenever they came under stress.

The US National intelligence estimate on the terrorist threat to the U.S. Homeland and statement of top administrative hierarchy reflects that al-Qaida leadership minus the Osama are comfortably ensconced in the Pakistan-Afghan (National Intelligence Estimate,2012,p.24). The jihadi culture in FATA area owes its existence to the primacy of small arms. The Robin Hood way, everyone has a weapon, you just need a stimuli to cross the line and join the either of the Taliban initially and if one is really into it the subsequent alleviation to higher terrorist organization like Al Qaida etc takes place as the corollary. The decision to join such organizations is the first step for which not much pondering is done as the stimuli to join are in abundance. As Napoleon said that "decision is two-third information and analysis and one-third leap in the dark". In this case it is the mere leap.

Taliban is the basic phenomenon which has spread jihadism in the tribal areas of Pakistan. Tehrik-e-Taliban Pakistan is the forerunner in this aspect. It is over twenty thousand strong with a bigger segment of Masood tribe and also affiliates from TNSM (Tehrik-a-Nifaz and Shari-a-Muhammadi). Taliban in the FATA area have become the hydra headed, network, removal of leadership through strong operation or surgical strikes effects no more, the rank and file as there is a line of people to fill such gap. 


\section{Afghan Taliban and FATA}

ZabiUllah Mujahid, the spoken person of Afghan Taliban described Kandahar jail break as pre planned. Afghan Taliban are fully trained and a well oiled machine, who aspire to recapture Afghanistan from the clutches of foreign powers. Afghan Taliban are led by Siraj Haqqani who is the son of Jalal Uddin Haqqani based in south eastern Afghanistan. He had a lot of affiliation with FATA as he during the Afghan Jihad period dad been brought up at Miran Shah, the capital of North Waziristan agency.

The Afghan Taliban have applied the policy of positive engagement with security apparatus of Pakistan in FATA, they do not indulge in confrontation with the exception of Bajaur where one of insurgency commander is a Afghan Taliban. Afghan Taliban's area of interest is Afghanistan but never the less they have tacit presence in FATA without disturbing the internal equilibrium of Pakistani state.

\section{Tehrik-e-Taliban Pakistan and FATA}

In the year 2002 Pakistani troops entered the Tirah valley and Shawal valley to capture the foreign elements. The tribes objected to this exercise and showed mild resistance in the beginning. But the military persuaded to accomplish their mission which created frictions and an open resistance broke between the tribal renegades and the Army. These are the forerunners of Pakistani Taliban.

In year 2007 Bait Ulla Masood created an alliance of 13 different resistance group and named it as Tehrik-e-Taliban Pakistan (Strick, Kuehn, 2012,p.490). The present leader of TTP Hakim Ullah Masood was then a middle level leader having tribal affinity with Bait Ullah Masood. In year 2009 Mullah Omer influenced TTP to strike a deal with Afghan Taliban and other factions to concentrate on Afghan theater, this was named Shura-i-Jihad-e-Mujahideen.

TTP is responsible for an open, declared and diabolic insurgency against the state of Pakistan. TTP conducts terrorist attacks against Pakistan Army and takes the state of Pakistan as its enemy. The proclaimed aims are to fight Pakistani state and enforce sharia.

\section{FATA and the War of Ideas and Perception}

As already mentioned it is very difficult in the tribal area to differentiate between an Afghan Taliban or a Pakistani Taliban. Because both are from the same broader stock. The war against Tehrik-a-taliban Pakistan is the war of perceptions and the war against Afghan Taliban by allied troops is the war of ideas or ideology. Both the tangents however intermingle at the horizon of political thought of Taliban. It is very important that the prevalent perception of the tribals about war on terror, Pakistan Army, Pakistani state, Allied troops, Drones and number of other issue be under stood.

These perceptions are tabulated below so that the pertinent inferences are drawn at the culminating point of this study:-

a. USA cannot win a war in Afghanistan without the help of Pakistan. This perception leads Afghan Taliban to adopt the policy of, to run with the hare and hunt with the hound. 
b. The USA will not leave Afghanistan giving 2014 as the date of withdrawal is to pacify the allied armies in Afghanistan who are getting varied of this war.

c. The development strategy of Pakistan and USA both in tribal area is Malik specific, there is no out reach programme to benefit the general masses.

d. Tribals think that Pakistani state is in tacit connivance for the drone attacks. Each drone attack is actually the recruitment call for Pakistani Taliban.

e. It is perceived that the ingress of India is not only taking place in Afghanistan rather Pakistani Taliban are also blamed to have Indian connection (Mir, 2009, p.373).

f. The socia-economic condition of FATA will not change unless the local people are involved into these programmes and leakages of funds are taken care of.

g. Pakistan Army is seen as an alien force inside FATA and is perceived to fighting its own people in its own territory.

h. The cultural differential of Pakistan army with the tribal is so wide that the common ground is difficult to reach.

i. Pakistani state is not interested in the implementation of Sharia law in FATA area.

Unfortunately the weapon balance that is of small arms has shifted in favor of the tribals except the heavy weapon (Aero plane \& Tanks); the insurgents are highly mobile and fighting Toyota wars. The demographic bulge is tilting the balance towards the insurgents, in this back drop the above mentioned perceptions will act as tinder to fire.

Nikat - Demographic Fault line

North Waziristan is demographically a stable state with Wazirs in majority and Daurs as a minority. But South Waziristan is demographically unstable. Before 1972 Mahsud used to be in majority, it is still like that but the Mahsud proportion in population is declining and that of Wazirs is increasing, there is an historic rivalry in south Waziristan between Mahsud and Wazir, to settle the issue in 1950, government introduced the system of nikat that is to distribute three fourth of development fund to Masud and one-fourth to Wazirs. Wazirs are not ready to accept it and there is a lot of hidden acrimony due to this.

\section{Waziristan - The Nemesis}

Due to the military operation Rah-a-Nijat in 2009, the demography of south Waziristan specially south of Razmak has further changed. The Masuds left the area on droves and now the villages are empty. This has again proved to be a fillip in the talibanization of the Waziristan. The Mullah has gained a new status of an arbitrator between tribes and the state. The famous Shakai deal between Nek Muhammad and the state was also accentuated by the clerics of the area. Unfortunately the tribal society has reshaped itself around the militants and the Paksitani Taliban has mastered the art of establishing alternative centers for the dispensation of justice and settling the dispute.

In simple words the Pashtuns nationalism has taken the shape of religious nationalism. And 
the amalgamation of culture and religion has taken the shape of a new type of political Islam.

The insurgency in Afghanistan is lead by Haqqani under the leadership of Mullah Omer, it seems interesting to note that due to the ever increasing influence of Haqqani, let us see that eventually which shura prevails, the Quetta or the Waziristan.

Taliban Groups in Waziristan

\begin{tabular}{|c|c|c|c|c|c|}
\hline No & Name & Sect & Tribe & Head & $\begin{array}{l}\text { Area } \\
\text { concentration }\end{array}$ \\
\hline $\mathbf{1}$ & $\begin{array}{l}\text { Baitullah } \\
\text { Group }\end{array}$ & Deobandi & Mehsud & $\begin{array}{l}\text { Baitullah } \\
\text { Mehsud }\end{array}$ & SWA \\
\hline 2 & $\begin{array}{l}\text { Shehryar } \\
\text { Group }\end{array}$ & Deobandi & Mehsud & $\begin{array}{l}\text { Shehryar } \\
\text { Mehsud }\end{array}$ & \\
\hline 3 & $\begin{array}{l}\text { Said Alam } \\
\text { Group }\end{array}$ & & Mehsud & Said Alam & SWA \\
\hline 4 & $\begin{array}{l}\text { Mullah } \\
\text { Nazir } \\
\text { Group }\end{array}$ & Deobandi & $\begin{array}{l}\text { Ahmadzai } \\
\text { Wazir }\end{array}$ & $\begin{array}{l}\text { Mullah } \\
\text { Nazir }\end{array}$ & SWA \\
\hline 5 & $\begin{array}{l}\text { Abbas } \\
\text { Group }\end{array}$ & Deobandi & $\begin{array}{l}\text { Ahmadzai } \\
\text { Wazir }\end{array}$ & $\begin{array}{l}\text { Commander } \\
\text { Abbas }\end{array}$ & SWA \\
\hline 6 & $\begin{array}{l}\text { Noor Islam } \\
\text { Group }\end{array}$ & Deobandi & Ahmadzai & $\begin{array}{l}\text { Wazir Noor } \\
\text { Islam }\end{array}$ & SWA \\
\hline 7 & $\begin{array}{l}\text { Haji Sharif } \\
\text { Group }\end{array}$ & Deobandi & $\begin{array}{l}\text { Ahmadzai } \\
\text { Wazir }\end{array}$ & Haji Sharif & SWA \\
\hline 8 & $\begin{array}{l}\text { Haji Omer } \\
\text { Group }\end{array}$ & Deobandi & $\begin{array}{l}\text { Ahmadzai } \\
\text { Wazir }\end{array}$ & Haji Omer & SWA \\
\hline 9 & $\begin{array}{l}\text { Ghulam } \\
\text { Jan Group }\end{array}$ & Deobandi & $\begin{array}{l}\text { Ahmadzai } \\
\text { Wazir }\end{array}$ & Ghulam Jan & SWA \\
\hline 10 & $\begin{array}{l}\text { Javed } \\
\text { Group }\end{array}$ & Deobandi & $\begin{array}{l}\text { Karmazkhel } \\
\text { Wazir }\end{array}$ & $\begin{array}{l}\text { Commander } \\
\text { Javed }\end{array}$ & SWA \\
\hline 11 & Awal Khan & Deobandi & Bhittani & Commander & Jandola, SWA \\
\hline
\end{tabular}




\begin{tabular}{|c|c|c|c|c|c|}
\hline & Group & & & Awal Khan & \\
\hline 12 & $\begin{array}{l}\text { Angaar } \\
\text { Group }\end{array}$ & Deobandi & & & \\
\hline 13 & $\begin{array}{l}\text { Bhittani } \\
\text { Group }\end{array}$ & Deobandi & Bhittani & $\begin{array}{l}\text { Asmaatullah } \\
\text { Saheen }\end{array}$ & Jundola, SWA \\
\hline 14 & $\begin{array}{l}\text { Gul } \\
\text { Bahadar } \\
\text { Group }\end{array}$ & Deobandi & $\begin{array}{l}\text { Utmanzai } \\
\text { Wazir }\end{array}$ & $\begin{array}{l}\text { Qari Gul } \\
\text { Bahadar }\end{array}$ & $\mathrm{NWA}^{2}$ \\
\hline 15 & $\begin{array}{l}\text { Daur } \\
\text { Group }\end{array}$ & Deobandi & Daur & Sadiq Noor & NWA \\
\hline 16 & $\begin{array}{l}\text { Khaliq } \\
\text { Haqani }\end{array}$ & Deobandi & Daur & $\begin{array}{l}\text { Abdul } \\
\text { Khaliq } \\
\text { Haqani }\end{array}$ & NWA \\
\hline 17 & Wahidullah & Deobandi & $\begin{array}{l}\text { Utmanzai } \\
\text { Wazir }\end{array}$ & Wahidullah & Spalga, NWA \\
\hline 18 & $\begin{array}{l}\text { Saifullah } \\
\text { group }\end{array}$ & Deobandi & $\begin{array}{l}\text { Turi Khel, } \\
\text { Utmanzai } \\
\text { Wazir }\end{array}$ & $\begin{array}{l}\text { Commander } \\
\text { Saifullah }\end{array}$ & NWA \\
\hline 19 & $\begin{array}{l}\text { Abdul } \\
\text { Rehman } \\
\text { group }\end{array}$ & Deobandi & Daur & $\begin{array}{l}\text { Abdul } \\
\text { Rehman }\end{array}$ & Mirali, NWA \\
\hline 20 & $\begin{array}{l}\text { Manzoor } \\
\text { group }\end{array}$ & Deobandi & Daur & $\begin{array}{l}\text { Commander } \\
\text { Manzoor }\end{array}$ & Eidaq, NWA \\
\hline 21 & $\begin{array}{l}\text { Haleem } \\
\text { Group }\end{array}$ & Deobandi & Daur & $\begin{array}{l}\text { Haleem } \\
\text { Khan }\end{array}$ & Mirali, NWA \\
\hline
\end{tabular}

Source: Amir Rana, Taliban insurgency, a counterinsurgency prespective, (Vol-II No.3), PIPS Research Journal, Islamabad, 2009, p.30 


\section{Waziristan and Game Theory}

The game theory appeared in 1944. The proponent was John Von Neumann. It is now being applied in conflict as well as for reaching decision making. In this case the Nash equilibrium is applied for the game between the government of Pakistan and the people of Waziristan.

Pakistan supported the Taliban regime of Mullah Umer just after Afghan Jihad in the hope that this will not only bring peace in Afghanistan, rather it will also prove to be a factor of internal harmony in the tribal areas of Pakistan. But Mullah Omer followed a non-flexible policy regarding Osama Bin Ladin and instead of becoming an asset became a liability for the Pakistani state.

The other factor had a nuclear dimension, Pakistan could not afford that after 9/11, India provide bases and facilities to USA and Pakistan is taken to the task by both the countries. Therefore Pakistan took a turn; it was not a U-turn because the Taliban were already showing defiance to Pakistan.

From 2004 till 2006 the Pakistan chased Al-Qaida and Taliban by counter terrorist measures and also by under taking large scale military operations in FATA. Notable arrests were, Syed Muhammad Hashim, Abdul Faraj Al libbi, Khalid Sheikh Muhammad, Arif Choto, and Omer Sheikh etc.

\section{Setting the Chess Board}

Waziristan is the ideal place for guerrilla warfare due to basket of the egg geography. The Ahmadzai Wazir and the Mahsud are known for their fighting skills. Historically when Mahmood Ghaznavi was unable to conquer Somnath due to the broad fire trenches. He was told to recruit Burkis, a sub-tribe of Mahsuds from Sararoga, who were then known to be the best horse riders, able to cross mountain gorges in one leap. Somnath fell due to same riders. This mentality still prevails in the minds of Masuds who are extremely ethno-religious centric.

The tribal of Waziristan took part whole heatedly in US backed Afghan Jihad against former USSR. Now they consider the present conflict as Afghan jihad-II. It started in 2004 when the army moved in, the army camp in North Waziristan came under attack.

On Feb 23, 2006 the governor of Khyber Pakhtun Khawa announced that government has suspended operation in North Waziristan.

The peace agreement of Aug 2006 had the following main clauses:-

a. Army personnel and state properties will not be attacked.

b. No cross boarder movement to Afghanistan will be carried out and no target killing will be done.

c. Foreigner in North Waziristan will leave.

d. Those arrested by the government will be released. 
e. The tribal customs will be respected.

\section{Nash - Equilibrium the Game of Pay-Offs}

Now as we know that the Nash equilibrium is the game of pay offs. So the tribe in Waziristan concentrated to develop ties with Afghan Taliban on one hand and also Pakistani Taliban when it emerged in 2007. On the other hand, Pakistani Government tried to apply Nash equilibrium by calculating the pay-off in strategic terms.

The desire to maintain good relations with USA and at the same time having relations with Afghan Taliban, this from the very beginning created a null equilibrium for Pakistan. The biggest stimuli of pay off for the Taliban in Waziristan were the Pakhtunwali. So the principle of confronting and yet supporting Taliban by Pakistan is a unique Nash equilibrium.

Pakistan government was left with four strategic options, peace-peace, peace-war, war-peace, and war-war. As a result of probably not counting the pay offs accurately, today Pakistan army is over stretched, the number of new fronts coming up are increasing, the problem of sub national insurgency is also brewing in Baluchistan. On the other hand Taliban are benefiting from the rising anti American sentiments, in Waziristan and also anti army posture of tribals due to prolonged sufferings.

\section{Political Economy of Taliban}

For the sustenance and contiguity of these operations, Taliban needs to have a non-stop, unabated and continues flow of money. The political economy of Taliban is shaded, it is half black and the other half grey in color. Black economy of Taliban depends almost entirely upon the dubious sources.

Another major source is the philanthropist dole out from Middle East and the collection of alms from within the Pakistani society by Jihadi organizations, who further transfer some of their funds to Taliban in exchange of availability of sanctuaries in FATA area.

Drug Trade - Taliban's Black money

Drug is taken as a source of financing for illicit operations. The money is called as operational finance. The money trail is usually blazing, very difficult to follow. In the South America the security issues are related to Drug trade and trafficking (Alexander, 2003, pp. 172-173) ${ }^{2}$.

Same way the idea of using drug money is not an innovation of Pakistani Taliban, Afghan Taliban or Al-Qaida. Criminal groups does this as the Maoist insurgent did in Nepal, the Sri Lankan Tamil moved Burmese heroin (low quality) to west. Even Hezbullah is reported to have generated funds through drugs in Lebanon's Bekaa Valley (Peters, 2009, p.10).

Afghanistan since decades is famous for the poppy production. First it used to be of raw kind, now it is crystallize heroine. Afghanistan became a popular stop on the hippie trail in 1966 because of its cheap hashish and striking scenery. 


\section{Macrothink}

Journal of Public Administration and Governance ISSN 2161-7104 2012, Vol. 2, No. 4

The opium income in Afghanistan is estimated to be of 4.8 billion dollars per year. Because of this incentive in 2006 Afghanistan produced largest illicit crop in the history, of which two-third was grown in Taliban area.

The money trail for such big drug operation is settled through Hawala system. This can not be traced and covers the globe as a cobweb of criminality (Coll, 2004, p.524).

It is now evident that the socio-political conditions in FATA, Waziristan and along Durrand line are ideal for the growth of obscuranticism.

\section{References}

1. Olaf Caroe, 'The Pathans' (London, Macmillan Company,1965),p.25.

2. Olaf Caroe, 'The Pathans' (London, Macmillan Company,1965),p.435.

3. Tepu Mahabat Khan, 'Tribal Areas of Pakistan', (Lahore, Sang-e-meal Publications, 2008), pp.16-19.

4. "1956 Constitution of Pakistan", p.42, downloaded from http://www.studyofpakistan.com, on 12 Feb 2012.

5. Constitution of Pakistan, 1973, chapter7, Article 247, section2,p.97.

6. Shuja Nawaz, 'FATA - A Most Dangerous Place', (New York, Study published by CSIS 2009), p.25.

7. Tepu Mahabat Khan, 'Tribal Areas of Pakistan', (Lahore, Sang-e-meal Publications, 2008), p.104.

8. Naveed Ahmed Shinwari, Understanding FATA 'volume IV, (Islamabad, CAMP, 2010), p.53.

9. Tepu Mahabat Khan, 'Tribal Areas of Pakistan', (Lahore, Sang-e-meal Publications, 2008), p.109.

10. Alex Strick, Felix Kuehn. "An Enemy We Created”(London. Hurst and Co, 2012). pp. 77-82.

11. Olaf Caroe, 'The Pathans' (London, Macmillan Company,1965),p.38.

12. Dr. Noor Ul Haq, Dr. Maqsdul Hassan Nuri, 'Federerally Administrated Tribal Area,Study Published by ISSI, Islamabad, 2009, p.37.

13. Irfan Ghani, 'Political Reform” A centuary laler', Tribune, (Islamabad, August 12, 2011, p.8)

14. Dr Noor-Ul-Haq, 'Pak Afghan Relation', IPRI, Fact file No, 44, p.12, downloaded from http/ipripak.org/factfile/ff44 on $9^{\text {th }}$ Jan 2012. 


\section{Macrothink}

Journal of Public Administration and Governance ISSN 2161-7104 2012, Vol. 2, No. 4

15. National Intelligence Estimate, 'The Terrorist Threat to the U/S homeland', downloaded from http//nie,cia.com on 15 Jan 2012,p.24.

16. Alex Strick, Felix Kuehn. “An Enemy We Created” (London. Hurst and Co, 2012). p.490.

17. Amir Mir, 'Talibanisation of Pakistan', (New Delhi, Pentagon Security

International, 2009), p.373.

18. John B. Alexander, 'Winning The War', (New York, Martian Press, 2003), pp.172-173.

19. Gretehen Peters, 'Seeds of Terror', (Dehli, Hachette, 2009), p.10.

20. Steve Coll 'Ghost Wars', (England, Penguin Books, 2004), p.524.

21. Jason Burke, 'Al-Qaida', (England, Penguin Books, 2007), p.127. 